\title{
Strategies in Vocabulary Acquisition
}

\author{
Fauzan Atsari \\ English Department \\ Universitas Islam Negeri Sunan Ampel \\ Surabaya, Indonesia \\ Fauzanatsari26@gmail.com
}

\begin{abstract}
Various researches have been conducted in field of Language Acquisition. Generally, linguists group the process of acquiring language into first and second language acquisition. In addition, there is also term vocabulary acquisition which refers to the process of acquiring vocabulary. In fact, the term acquisition is interpreted differently by language researchers. Some researchers distinguish between acquiring and learning. On the other side, other researchers assume those terms as the same. In this research, the researcher refers to the notion that those two are similar. The process of acquiring vocabulary is influenced by many factors. Some of the factors found by language researchers are first language background, motivation, and learning strategies. Learning strategies itself can be divided to some types such as direct and indirect strategies which each of them contains three sections. Strategies in learning vocabulary are often used by advanced students than intermediate and elementary students. This research tried to investigate students' reason for using particular strategies. In the end of this research, the researcher found that the results were varied on each problem. Each of them was different based upon factors influencing each subject.
\end{abstract}

Keywords - language acquisition, vocabulary acquisition, learning strategies

\section{INTRODUCTION}

There are many factors influencing SLA [second language acquisition] and vocabulary acquisition. Age is one of the factors that is considered as a major variable affecting the process of SLA [1]; [2]; [3]; [4]; [5]; [6]. There is also L1 [first language] background that takes an important role in vocabulary acquisition [5]; [7]; [8]. On the other side, motivation is regarded as one of the crucial factors affecting the process of vocabulary acquisition [2]; [3]; [9]; [10]; [11]. Furthermore, ref [12], [5], and [13] declared learning strategies as imperative and influential factor in the process of vocabulary acquisition.

One of the researches in learning strategies has been done by ref [14]. His research uses a classification made by Shirahata, Tomita, Muranoi, and Wakabayashi cited in ref [14] which classify learning strategies into two major classes; direct and indirect strategies, and six groups; cognitive, memory, compensation, metacognitive, affective, and social strategies.

He conducted his research on 148 students enrolled in liberal arts English classes in a university in Iwate, Japan. $\mathrm{He}$ divided language learners into three categories based on the score of 'Test of English as a Foreign Language Instructional Testing Program [TOEFL ITP] level 2 test' which were elementary, intermediate, and advanced.

In his research, he found that advanced students used more strategies than intermediate students. The intermediate students used more strategies than elementary students. Yet, the pattern of the six strategies used in three different classes were almost the same. He also mentioned that the strategy that the most widely used was the same; translating [cognitive]. However, he did not analyze the reason they choose their strategies. Whereas, there must be reason for every learner in applying particular learning strategy.

This study indicated that every subject applied different strategies in learning English as their second language. This research uses case study research design which is designed for answering 'why' question. Case study research allows the researcher to inspect the data within a specific content [15]; [16]. In this case, the researcher selected a tiny number of individuals from small geographical area as the subjects of the study. The research findings showed that their reason for choosing certain strategies were varied based on the circumstance and need.

\section{A. VOCABULARY ACQUISITION}

One of the important parts in learning language is vocabulary acquisition. Considering learning language is not only about understanding grammar and structure, vocabulary becomes a crucial part of language to be learned. One of the reasons is because no human - even with great grammar skill - can convey any message without vocabulary [17]. Basically, every language learner was well aware of the fact that learning second language would not be separated from learning huge numbers of words [18]. There had been so many researches that had been done in vocabulary acquisition. 
The first research was conducted by ref [19]. In their research, they mentioned three essential ways in which children's school experiences may contribute to growth in their vocabularies. The first way was by direct order or command in individual word meanings. The second was by incidental learning from verbal context. The third was by combination of direct instruction and verbal context. Furthermore, they also mentioned some variables that influenced the learning of word meanings from context: connection between the unfamiliar word and the context clue, the proximity of the unfamiliar word and the context clue, the reader's experience in using contextual clues, the type of target word, the age of the learner, and the reading ability of the learner.

The second research was done by ref [18] which discussed not only the acquisition of vocabulary but also grammar knowledge. On the discussion of vocabulary acquisition, they said that the way human process information may affected by motivation, emotion, and socio-cultural factors. They also added that learning thousands of words was normally required in the second language acquisition process.

\section{B. LEARNING STRATEGIES}

Learning strategies are behavior and idea that can help learners to learn, understand, and remember new information better [20]. The use of strategy in learning is one of the factors giving big influence for the success of learning process [21].

Furthermore, language learning strategies can be interpreted as techniques or methods used by learners to improve and facilitate the language acquisition process [22]. There are many classifications of language learning strategies made by scholars. One of the classifications of language learning strategies is as proposed by Shirahata, Tomita, Muranoi, and Wakabayashi cited in ref [14].

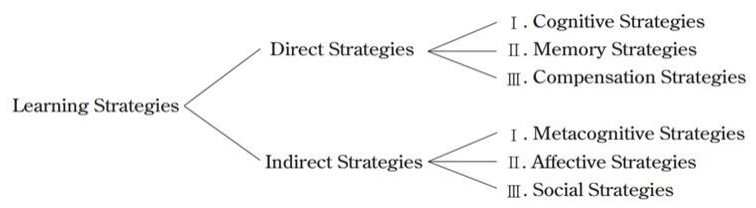

The details for each strategy are as follow:

TABLE 1: Cognitive Strategies

\begin{tabular}{|c|c|c|}
\hline \multicolumn{3}{|c|}{ Direct Strategies } \\
\hline \multirow{4}{*}{$\begin{array}{c}\text { Cognitive } \\
\text { strategies }\end{array}$} & Repeating \\
\cline { 3 - 3 } & Practicing & $\begin{array}{c}\text { Formally practicing } \\
\text { with sound system }\end{array}$ \\
& $\begin{array}{c}\text { Formally practicing } \\
\text { with writing system }\end{array}$ \\
& $\begin{array}{c}\text { Recognizing and } \\
\text { using formulas and } \\
\text { patterns }\end{array}$ \\
\hline
\end{tabular}

\begin{tabular}{|c|c|c|}
\hline \multirow{4}{*}{$\begin{array}{c}\text { Receiving and } \\
\text { sending message }\end{array}$} & $\begin{array}{c}\text { Recombining } \\
\text { quickly }\end{array}$ \\
\cline { 3 - 3 } & $\begin{array}{c}\text { Using resources for } \\
\text { receiving and } \\
\text { sending messages }\end{array}$ \\
\cline { 2 - 3 } & $\begin{array}{c}\text { Analyzing } \\
\text { expressions }\end{array}$ \\
\cline { 2 - 3 } $\begin{array}{c}\text { Analyzing and } \\
\text { reasoning }\end{array}$ & $\begin{array}{c}\text { Analyzing } \\
\text { contrastively }\end{array}$ \\
\cline { 3 - 3 } & Translating \\
\cline { 2 - 3 } & $\begin{array}{c}\text { Transferring } \\
\text { Creating structure } \\
\text { for input and } \\
\text { output }\end{array}$ & Taking notes \\
\cline { 2 - 3 } & & Summarizing \\
\cline { 2 - 3 } & & Highlighting \\
\hline
\end{tabular}

TABLE II: Memory Strategies

\begin{tabular}{|c|c|c|}
\hline \multicolumn{3}{|c|}{ Direct Strategies } \\
\hline \multirow{10}{*}{$\begin{array}{l}\text { Memory } \\
\text { Strategies }\end{array}$} & \multirow{3}{*}{$\begin{array}{c}\text { Creating mental } \\
\text { linkages }\end{array}$} & Grouping \\
\hline & & Associating/elaborating \\
\hline & & $\begin{array}{c}\text { Placing new words into a } \\
\text { context }\end{array}$ \\
\hline & \multirow{4}{*}{$\begin{array}{l}\text { Applying } \\
\text { images and } \\
\text { sounds }\end{array}$} & Using imagery \\
\hline & & Semantic mapping \\
\hline & & Using keywords \\
\hline & & $\begin{array}{l}\text { Representing sounds in } \\
\text { memory }\end{array}$ \\
\hline & Reviewing well & Structured reviewing \\
\hline & \multirow{2}{*}{$\begin{array}{l}\text { Employing } \\
\text { actions }\end{array}$} & $\begin{array}{c}\text { Using physical responses } \\
\text { or sensation }\end{array}$ \\
\hline & & $\begin{array}{c}\text { Using mechanical } \\
\text { techniques }\end{array}$ \\
\hline
\end{tabular}

TABLE III: Compensation Strategies

\begin{tabular}{|c|c|c|}
\hline \multicolumn{3}{|c|}{ Direct Strategies } \\
\hline \multirow{8}{*}{$\begin{array}{c}\text { Compensation } \\
\text { Strategies }\end{array}$} & \multirow{3}{*}{$\begin{array}{l}\text { Guessing } \\
\text { intelligently }\end{array}$} & $\begin{array}{l}\text { Reasoning } \\
\text { deductively }\end{array}$ \\
\hline & & $\begin{array}{l}\text { Using linguistic } \\
\text { clues }\end{array}$ \\
\hline & & Using other clues \\
\hline & \multirow{5}{*}{$\begin{array}{l}\text { Overcoming } \\
\text { limitations in } \\
\text { speaking and } \\
\text { writing }\end{array}$} & $\begin{array}{l}\text { Switching to the } \\
\text { mother tongue }\end{array}$ \\
\hline & & $\begin{array}{l}\text { Using mime or } \\
\text { gesture }\end{array}$ \\
\hline & & $\begin{array}{c}\text { Avoiding } \\
\text { communication } \\
\text { partially or totally }\end{array}$ \\
\hline & & Selecting the topic \\
\hline & & Adjusting or \\
\hline
\end{tabular}




\begin{tabular}{|c|c|c|}
\hline \multirow{5}{*}{} & $\begin{array}{c}\text { approximating the } \\
\text { message }\end{array}$ \\
\hline & $\begin{array}{c}\text { Coining words } \\
\text { Using a } \\
\text { circumlocution or } \\
\text { synonym }\end{array}$ \\
\hline & Getting help \\
\hline
\end{tabular}

TABLE IV: Metacognitive Strategies

\begin{tabular}{|c|c|c|}
\hline \multicolumn{3}{|c|}{ Indirect Strategies } \\
\hline \multirow{11}{*}{$\begin{array}{l}\text { Metacognitive } \\
\text { strategies }\end{array}$} & \multirow[t]{2}{*}{$\begin{array}{l}\text { Centering your } \\
\text { learning }\end{array}$} & $\begin{array}{l}\text { Overviewing and } \\
\text { linking with } \\
\text { already material }\end{array}$ \\
\hline & & Paying attention \\
\hline & \multirow{7}{*}{$\begin{array}{l}\text { Arranging and } \\
\text { planning your } \\
\text { learning }\end{array}$} & $\begin{array}{l}\text { Finding out about } \\
\text { language learning }\end{array}$ \\
\hline & & Organizing \\
\hline & & $\begin{array}{c}\text { Setting goals and } \\
\text { objectives }\end{array}$ \\
\hline & & Planning \\
\hline & & $\begin{array}{l}\text { Identifying the } \\
\text { purpose of } \\
\text { language task }\end{array}$ \\
\hline & & $\begin{array}{l}\text { Planning for a } \\
\text { language task }\end{array}$ \\
\hline & & $\begin{array}{l}\text { Seeking practice } \\
\text { opportunities }\end{array}$ \\
\hline & \multirow{2}{*}{$\begin{array}{c}\text { Evaluating your } \\
\text { learning }\end{array}$} & Self-monitoring \\
\hline & & Self-evaluating \\
\hline
\end{tabular}

TABLE V: Affective Strategies

\begin{tabular}{|c|c|c|}
\hline \multicolumn{3}{|c|}{ Indirect Strategies } \\
\hline \multirow{10}{*}{$\begin{array}{l}\text { Affective } \\
\text { strategies }\end{array}$} & \multirow[t]{3}{*}{$\begin{array}{l}\text { Lowering your } \\
\text { anxiety }\end{array}$} & $\begin{array}{l}\text { Using progressive } \\
\text { relaxation, deep } \\
\text { breathing, or } \\
\text { mediation }\end{array}$ \\
\hline & & Using music \\
\hline & & Using laugher \\
\hline & \multirow{3}{*}{$\begin{array}{l}\text { Encouraging } \\
\text { yourself }\end{array}$} & $\begin{array}{l}\text { Making positive } \\
\text { statements }\end{array}$ \\
\hline & & $\begin{array}{c}\text { Taking risks } \\
\text { wisely }\end{array}$ \\
\hline & & $\begin{array}{c}\text { Rewarding } \\
\text { yourself }\end{array}$ \\
\hline & \multirow{4}{*}{$\begin{array}{l}\text { Taking your } \\
\text { emotional } \\
\text { temperature }\end{array}$} & $\begin{array}{l}\text { Listening to your } \\
\text { body }\end{array}$ \\
\hline & & Using a checklist \\
\hline & & $\begin{array}{l}\text { Writing a language } \\
\text { learning diary }\end{array}$ \\
\hline & & $\begin{array}{l}\text { Discussing feeling } \\
\text { with someone else }\end{array}$ \\
\hline
\end{tabular}

TABLE VI: Social Strategies

\begin{tabular}{|c|c|c|}
\hline \multirow{4}{*}{ Indirect Strategies } \\
\hline \multirow{4}{*}{ Asking questions } & $\begin{array}{c}\text { Asking for } \\
\text { clarification }\end{array}$ \\
\cline { 3 - 3 } & $\begin{array}{c}\text { Asking for } \\
\text { verification }\end{array}$ \\
\cline { 2 - 3 } Social strategies & $\begin{array}{c}\text { Asking for } \\
\text { correction }\end{array}$ \\
\cline { 2 - 3 } & $\begin{array}{c}\text { Organizing } \\
\text { network }\end{array}$ & $\begin{array}{c}\text { Making friends with } \\
\text { peers }\end{array}$ \\
\cline { 2 - 3 } & $\begin{array}{c}\text { Making friends with } \\
\text { proficient users of } \\
\text { the new language }\end{array}$ \\
\cline { 2 - 3 } & $\begin{array}{c}\text { Cooperating with } \\
\text { peers }\end{array}$ \\
\cline { 2 - 3 } & Cooperating with \\
others & $\begin{array}{c}\text { Cooperating with } \\
\text { proficient users of } \\
\text { the new language }\end{array}$ \\
\cline { 2 - 3 } & $\begin{array}{c}\text { Developing cultural } \\
\text { understanding }\end{array}$ \\
\cline { 2 - 3 } & $\begin{array}{c}\text { Becoming aware of } \\
\text { others' thoughts and } \\
\text { feelings }\end{array}$ \\
\hline
\end{tabular}

Language learning strategies are divided into two major classes and six groups. The first class is called as direct strategies. It is the class of language learning strategies which related to direct learning process. Direct strategies are divided into three groups based on the process. They are cognitive, memory, and compensation strategy. Cognitive strategies allow learners to understand and produce new language by many different means. Memory strategies help learners to keep and recover new information. Compensation strategies help learners to overcome knowledge gaps to continue the communication.

The second class is called indirect strategies. It is the class of language learning strategies which supports and manages the process of language learning without entangling or involving to the target language directly. Indirect strategies are divided into metacognitive, affective, and social strategies. Metacognitive strategies deal with learners' cognition or how they control their learning process. Affective strategies deal with emotion management of learners [23]. Social strategies let the learners face the opportunity to expose with other people to gain knowledge [24].

\section{FINDINGS ON REASONS FOR CHOOSING STRATEGIES}

\section{A. Subject 1}

There were seventeen learning strategies considered as used frequently by Subject 1 . It consisted of four cognitive strategies, three memory strategies, three compensation 
strategies, a metacognitive strategy, four affective strategies, and two social strategies.

From the group of cognitive strategies, Subject 1 chose to use formally practicing with sound system because it made words memorizing easier when he imagined the sound. In other words, he recalled his memory by remembering the way it pronounced. Next, he considered to use analyzing expression although it did not applied during the observation period. His reason for using it was because sometimes he could get the meaning of the word by knowing the expression of people who state it. For example, although he did not know the meaning of the interjection 'Really?!', he could get the meaning - or at least hint - by analyzing the expression of people who utter or express it. Further, he considered to use translating just because it was easy. He claimed that, by using this strategy, he can directly know the meaning of words in his mother tongue. Then, taking notes was chosen by him because it makes him easy to relearn what had been learned.

From the group of memory strategies, Subject 1 selected to apply using imagery because it makes him directly imagine the form of a thing that was related to the word he wanted to remember. Whereas using keywords was used to recall the forgotten vocabulary items. The next was repeating sound in memory that was chosen by him just because of simple.

From the group of compensation strategies, Subject 1 considered to like switching to the mother tongue because it was easy to understand when using the mother tongue. Likewise, using mime and gesture was also chosen because it makes the communication easier. Not much different, using $a$ circumlocution or synonym was chosen just because he considered it as easier than others to be applied.

From the group of metacognitive strategies, the only strategy that considered by him as frequently used was selfevaluating. His reason to use this strategy was because he did not like scheduling in the beginning. He preferred to evaluate his activity in the end. It was because, if he planned his activity in the beginning, usually it would not be as planned.

From the group of affective strategies, Subject 1 considered to use four strategies. The first was using progressive relaxation, deep breathing, or meditation which makes his motivation and spirit uplifted. The second was using music which was used only for accompanying him, not to be listened. He added, if he learned together with his friends, he usually could not learn because the situation would be crowded. So he preferred to learn alone, accompanied by music. The third was using laugher which was chosen just because he was a kind of person who like to joke. The last was discussing feeling with someone else which was chosen because it could lower his anxiety.

From the group of social strategies, Subject 1 chose to use two strategies. The first was asking for correction which was applied in four observations. His reason to like this strategy was there were some cases in which he became uncertain to his thought. So, he would ask whether it was correct or not. The second was developing cultural understanding. He chose to use this strategy because it could make him know the background of his interlocutors.
Overall, Subject 1 chose direct strategies that could help him getting and memorizing vocabulary directly, such as translating, taking notes, and using imagery. Otherwise, indirect strategies that applied by him was chosen because they could support him obtaining vocabulary indirectly. For example, by raising his mood or making his learning more structured.

\section{B. Subject 2}

There were thirteen learning strategies considered as used frequently by Subject 2. It consisted of three cognitive strategies and two of each other strategy.

From the group of cognitive strategies, Subject 2 liked to use formally practicing with writing system because he considered himself as a kind of forgetful person. So, he usually wrote what had been explained by his lecturer or other people so he could see his note when he forgot. The second cognitive strategy he liked to use was translating. It was applied by him in every observation period. His reason to like this strategy was because he did not like to use the same words for many times. By translating, he would see many translations of first language to second language. For example, when we translate the word 'besar' from Indonesia to English, he would get more than one vocabulary. There were 'big', 'huge', 'great', etc. The third was taking notes. He liked to use this strategy because he felt that he was a kind of person who was easy to forget.

From the group of memory strategies, Subject 2 liked to use imagery and keywords. His reason to like using imagery was because imagery would help him catching the point or meaning of the text. Meanwhile, using keywords was chosen for the same reason as taking notes, that is, because he felt that he often forgets necessary vocabulary.

From the group of compensation strategies, Subject 2 chosen using linguistic clues to ease him by getting explanation or elucidation of any vocabulary from linguistic clues. The next was getting help that helped him getting support, help, or assistance from other people.

From the group of metacognitive strategies, Subject 2 preferred planning and self-evaluating. Planning was preferred because he felt hard to focus on more than one thing. It made him need to plan to make his activity - including learning structured. Furthermore, self-evaluating was preferred because he felt having many shortcomings.

From the group of affective strategies, Subject 2 considered to like making positive statements because it could improve his spirit, especially in learning. Furthermore, he also claimed to like using discussing feeling with someone else. $\mathrm{He}$ said that, by telling his feeling to another person, he would feel relieved and more comfortable in learning.

From the group of affective strategies, he liked to use asking for correction which was applied in three observations. His reason was because he thought that he usually made mistake. Therefore, he needed correction from other people. In addition, cooperating with peers was the only strategy that he did not feel to apply frequently when he filled the questionnaires but once used when observed. His reason to use 
this strategy was to make him easy to complete huge number of task that might be hard to do by himself.

From the reason declared by Subject 2, it could be concluded that he used strategy based on his current situation and condition. For example, taking note was used because he felt that he was a forgetful person. Meanwhile, planning and self-evaluating were used because he realized that he was a forgetful person.

\section{Subject 3}

There were seventeen learning strategies considered as used frequently by Subject 3. It consisted of five cognitive strategies, two memory strategies, two compensation strategies, four metacognitive strategies, three affective strategies, and a social strategy. Hence, he also used planning and self-evaluating.

From the group of cognitive strategies, Subject 3 considered to like applying formally practicing with sound system because he thought that sound system was made to help various kind of activities such as listening to music and watching movie in which he could get new vocabularies from them. Another cognitive strategy he liked to apply was recognizing and using formulas and patterns. He admitted that this strategy helped him in adjusting sentence. The next was getting the idea quickly which he used to improve his work that need various vocabulary like making short story. After that, he also liked to use taking notes. He applied this strategy in four observation periods. He argued that he liked to use taking notes because it can be applied anywhere and made him easy to remember things he noted. The last cognitive strategy he liked to apply was highlighting which was applied in three observation periods. The reason he liked this strategy was not much different from highlighting. Additionally, he said that, by highlighting, he could feel interested. When he felt interested to a word or phrase he highlighted, he would think further about it.

From the group of memory strategies, Subject 3 recognized liking semantic mapping and using keywords. $\mathrm{He}$ stated that he liked to apply semantic mapping to interpret the meaning of words in poem. It was because semantics deal with meaning. Hereafter, he said that he chose this strategy to do a search on online search engines.

From the group of compensation strategies, Subject 3 liked using linguistic clues and selecting the topic. He liked to apply using linguistic clues when reading English texts. He usually searched the clues of unknown words at nearby sentences. Then, selecting the topic, said Subject 3, was usually used when he wanted to make article. For example, when he wanted to make an article about cooking, he selected it as the topic then searched words that related to cooking.

From the group of metacognitive strategies, Subject 3 liked to use three strategies. The first was paying attention which he used in three observations. His reason to like this strategy was, by using paying attention, he could get what his lecturer or a book convey. The second was setting goals and objectives. $\mathrm{He}$ claimed to use this strategy when doing assignment. He preferred this strategy because he needed to prepare things required to achieve his goal in certain time. The third was seeking practice opportunities which he thought needed because, in each time he learned a theory, he needed to know not only the theory but also how to apply it. The fourth was self-evaluating. He felt that he always did wrong thing that made failure. Hence, when he returned home, he evaluated himself to find his mistake.

From the group of affective strategies, as in the metacognitive strategies, Subject 3 liked to use three strategies. The first was using music which he applied in each of the observation period. He said that he liked to use music because it created a relaxed atmosphere. He also applied using laugher in an observation although he did not consider to use it frequently when filling the questionnaire. When being interviewed, he said that it can refresh his mind when he was too focused and depressed. Likewise, for discussing feeling with someone else. In the questionnaire, he did not recognize to apply it in helping him acquire vocabulary but did it in the last observation period. He said that, when he had something jammed in mind, he need a friend to share and listen to his story.

From the group of social strategies, Subject 3 only applied a strategy. That was asking for clarification. His reason to use this strategy was to get direct information from people he asked, especially when he did not understand the utterance of the interlocutor.

From the recognition given by Subject 3 , it could be deduced that most of the strategies used by him were chosen because effective to be used by him. Some of those strategies were appropriate with his learning style which tends to be formal and needs focus and seriousness.

From the whole data gained, it can be concluded that the strategies chosen and the reason for choosing strategies by each subject was different. It was depended on several factors such as interest of each individual that applied the strategies and their condition when acquiring vocabulary. By way of explanation, desire was not the only factor that influenced their strategy choosing.

\section{DISCUSSION}

From the result gained, it could be seen that the reason or factor for choosing strategies were not only their interest but also the circumstances when they apply them. Taking notes was the most applied strategy during the observation period. It was related to the fact that all of the subjects are students. Their daily activity was not far from learning activity at university that involved note as one of the tools required.

Furthermore, they were in the age that made them usually feel love. It often made them influenced by love feeling. It made them unconsciously discuss their feeling in the middle of learning activity although they did not feel to use it frequently when filling the questionnaire.

Based on those findings, the researcher concluded that the factors they choose strategies were different. This finding was supported by ref [25] who mentioned some factors influencing strategy choice. Those are mode of study, target language, 
level of study, language use opportunities, age, gender, language learning experience, prior experience in the target language, motivation, and proficiency.

Moreover, the researcher found that the same strategy could be chosen based on different reasons. It could be seen on the intention of each subject to use taking notes. Subject 1 used it to ease him reviewing what he had learned. Subject 2 applied it to help him remembering the material he learned, since he felt that he was a forgetful person. Subject 3 used it not only to help him memorize the material he learned but also to develop his idea. It means that their strategy choice was affected by some individual and situational factors. This fact was appropriate for the result of the research conducted by Boonkongsaen [26] which found that the factors affecting learners' variation in the use of vocabulary learning strategy were their individual difference, situational and social factors, and learning outcomes.

It was also found that there were some strategies that were not used only for intended purpose. One of the examples was using music. Actually, it was a part of affective strategies which the main significance was to lower anxiety of its user [23]. Subject 1 was the one who used this strategy to find comfortability in learning. However, Subject 3 used it not only for making himself comfortable but also for acquiring vocabulary from the lyric of the music played. This case proved that the same strategy could affect differently on different user.

In addition, the factors influencing strategy choice, as had mentioned by ref [25], may affect not only strategy choice but also strength and weakness to each individual's perspective. It could be seen from different opinion given by each subject for self-evaluating. Subject 3 argued that this strategy had no weakness. Otherwise, Subject 2 admitted that this strategy was effective because it could rise his motivation to learn. On the other hand, Subject 1 said that this strategy was somewhat effective. It was because he used this strategy to remember what he had done. However, his activities were tended to have never scheduled. On the other word, he did his activity spontaneously.

\section{CONCLUSION}

From this study, it is revealed that their reason for choosing certain strategies were varied. Some strategies were chosen just because they liked it. The choosing of the strategies was usually based on the situational factors and personality of each subject. This finding supports the statement proposed by ref [28] that vocabulary learning strategy was not only necessary tool in describing and explaining the vocabulary development of foreign language but also a tool for empowering learners to make wise decision in what and how they learn.

The way each strategy takes role in vocabulary acquisition process was also depended on the subject who chose it. Using music, for example, was a strategy which could support the user's vocabulary learning and acquiring process by lowering their anxiety and improving motivation. However, a subject recognized that he could not only be helped in lowering anxiety by also learn new vocabulary from its lyrics. It means that a strategy might take different role in different subjects.

\section{References}

[1] VP. Collier, "The effect of age on acquisition of a second language for school," Occasional Papers in Bilingual Education, vol. 2, 1988.

[2] MN. Gömleksiz, "The effects of age and motivation factors on second language acquisition," Firat University Journal of Social Science, vol. 11, 2001, pp. 217-224

[3] S. Khasinah, "Factors influencing second language acquisition," English Language Teaching, vol. 2, 2014, 155-163.

[4] S. Krashen, "Factors influencing scond language acquisition," Englisia, vol. 1, 2014, pp. 256-269.

[5] L. Lin, 'The role of linguistics in second language classrooms,' American International Journal of Contemporary Research, vol. 4, 2014, pp. 42-47.

[6] FM. Rafik, "Story telling and vocabulary acquisition at the elementary level," Dessertation submitted in partial fulfilment of the requirements for the magister degree in Linguistic Science and English language teaching, Mentouri University, 2005.

[7] SD. Krashen, Second Language Acquisition and Second Language Learning, Oxford: Pergamon Press, 1981.

[8] M. Nazary, "The role of L1 in L2 acquisition: attitudes for Iranian University students," Novitas-ROYAL [Research on Youth and Language], vol. 2, 2008, pp. 138-153.

[9] S. Laraba, "Developing vocabulary strategies in learners of english at university level: first-year L.M.D students," Candidacy for the degree of Doctorat d'Etat in applied linguistics, Mentouri University Constantine, 2007.

[10] C. Li, "A research on second language acquisition and college english teaching," English Language Teaching, vol. 2, 2009, pp. 57-60.

[11] W. Lin-Fang, "A study of factors affecting collage students' use of ESL vocabulary learning strategies," International Journal of Humanities and Social Science, vol. 3, 2013, pp. 202-208.

[12] J. Abhakorn, "The implication of learner strategies for second or foreign language teaching," ARECLS, vol. 5, 2008, pp. 186-204.

[13] P. Zare, "Language learning strategies among EFL/ESL learners: a review of literature," International Journal of Humanities and Social Science, vol. 2, 2012, pp. 162-169.

[14] K. Azumi, "An experimental study of language learning strategies," Japanese University Learners of English, 2015, pp. 149-169.

[15] RK. Yin, Case study research. Design and methods, 3rd ed, California: Sage Publications, 2003.

[16] Z. Zainal, "Case study as research method," Jurnal Kemanusiaan, vol. 9, 2007, pp. 1-6.

[17] M. Siriwan, "English vocabulary learning strategies employed by Rajabhat University students," A Thesis submitted as partial fulfilment of the requirements for the degree of doctor of philosophy in English language studies, Suranaree University of Technology, 2007.

[18] B. Laufer and J. Hulstijn, "Incidental vocabulary acquisition in a second language: the construct of task-induced involvement, Applied Linguistics, vol. 22, 2001, pp. 1-26.

[19] DW. Moore, JF. Peno, and IA. Wilkinson, "Vocabulary acquisition from teacher explanation and repeated listening to stories: do they overcome the matthew effect?" Journal of Educational Psychology, vol. 94, 2002 23-33.

[20] A. Derakhshan, R. Tamaskani, and M. Faribi, "Issues in language learning strategies," International Journal of Social Science and Education, vol. 5, 2015, pp. 613-621.

[21] IMP. Martinez, "The importance of language learning strategies in foreign language teaching," Cuadernos de Filologia Inglesa, vol. 5, 1996, 103-120. 
[22] AA. Hardan, "Language learning strategies: a general overview," Procedia - Social and Behavioral Sciences, vol. 106, 2013, pp. 17121726

[23] M. Kozmonová, "Language learning strategies and their training in a primary english class," Diploma Thesis, Departmeng of English Language and Literature, Masaryk University, 2008.

[24] H. Burešová, "Social strategies in foreign language teaching," Diploma Thesis, Department of English Language and Literature, Masaryk University, 2007.

[25] CJ. White, "Metacognitive, cognitive, social and affective strategy use in foreign language learning: a comparative study," a thesis presented in partial fulfilment of the requirements of degree of $\mathrm{PhD}$. in applied linguistics. Massey University, 1993.

[26] N. Boonkongsaeng, "Factors affecting vocabulary learning strategies: a synthesized study," Naresuan University Journal, vol. 20, 2012, 45-53.

[27] M. Kozomová, "Language learning strategies and their training in a primary English class," Diploma Thesis, Department of English Language and Literature, Masaryk University, Brno, 2008.

[28] Y. Gu, "Learning strategies for vocabulary development," Reflection on English Language Teaching, vol. 9, 2010, pp. 105-118. 